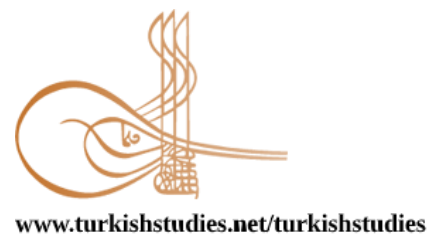

Turkish Studies

\title{
Covid-19 Salgınının Eğitime Etkisi Konusunda Okul Yöneticilerinin Görüşleri
}

\author{
School Administrators' Views on the Effect of Covid-19 Pandemic on Education
}

\author{
Ebru Külekçi Akyavuz* - Murat Çakın**
}

\begin{abstract}
The aim of the study is to determine the impact of the Covid-19 pandemic on education in line with the opinions of school administrators. In addition, the aim is to reveal how school administrators manage this process. Research has been designed as a phenomenological pattern from qualitative research types. The study group consists of school administrators working in kindergarten, primary school, middle school and high school. Maximum diversity sampling of sample types was used for the purposes of sample selection. School administrators from different provinces, different positions and different schools have been included to ensure maximum diversity in the sampling. A total of 37 school administrators participated in the study. The data were collected using a semi-structured interview form prepared by the researchers. A total of 6 main questions were in the interview form. In order to conduct this study, ethical committee permission was obtained from the Ethics Committee of Kilis 7 Aralık University (03.06.2020 date, 2020/13 no). The data were collected by researchers in April 2020. The school administrators taking part in the study group have been selected by reaching out to school administrators close to the researchers and other school administrators directed by these school administrators. Descriptive analysis was preferred in the analysis of the data. it was determined that the school administrators had problems within the education system during this period and that these problems were in the form of lack of communication, technical inadequacy, lack of knowledge, teachers' lack of interest and lack of planning. In other words, school administrators need to make their teachers, students, parents and assistant staff feel that they are supported in this process. It has been concluded that school administrators also have a role in providing motivation for parents and students, sometimes directly through themselves and sometimes through the teachers. For example, informing parents throughout the Covid-19 process and supporting their students both in terms of education and morale is an indication that school administrators are trying to reach out to all sections of the school in a time of crisis.
\end{abstract}

\section{Structured Abstract: Purpose}

The aim of the study is to determine the impact of the Covid-19 pandemic on education in line with the opinions of school administrators. In addition, the aim is to reveal how school administrators manage this process.

\footnotetext{
* Dr. Öğr. Üyesi, Kilis 7 Aralık Üniversitesi, Eğitim Fakültesi, Eğitim Bilimleri Bölümü Assist. Prof. Dr., Kilis 7 Arallk University, Faculty of Education, Department of Education Sciences. ORCID 0000-0002-2436-8761

ebrukulekci@kilis.edu.tr

*** Yüksek Lisans Öğrencisi, Kilis 7 Aralık Üniversitesi, Lisansüstü Eğitim Enstitüsü, Eğitim Bilimleri Bölümü

MA, Kilis 7 Arallk University, Institute of Graduate Programs, Department of Education Sciences.

ORCID 0000-0000-1111-1111

muratçakin84@gmail.com

Cite as/ Atıf: Külekçi Akyavuz, E., Çakın, M. (2020). Covid-19 salgınının eğitime etkisi konusunda okul yöneticilerinin görüşleri. Turkish Studies, 15(4), 723-737. https://dx.doi.org/10.7827/TurkishStudies.44140

Received/Geliș: 10 June/Haziran 2020

Accepted/Kabul: 10 August/Ağustos 2020

Checked by plagiarism software

Copyright (C) MDE, Turkey

Published/Yayın: 30 August/Ağustos 2020

CC BY-NC 4.0
} 
In this context, the following problems were answered:

According to the opinions of the school administrators, what are the problems encountered in the education process during Covid-19 pandemic?

According to the opinions of school administrators, how do they motivate their teachers during the Covid-19 process?

According to the opinions of school administrators, what are the methods used by school administrators to motivate students during the Covid-19 process?

According to the opinions of the school administrators, what are the activities they have done in order to raise awareness of the parents during the Covid-19 process?

\section{Method}

The qualitative research method was preferred since it provided an in-depth explanation of the school administrators' views regarding the reflection of the Covid-19 process on education. Research has been designed as a phenomenological pattern from qualitative research types. The study group consists of school administrators working in kindergarten, primary school, middle school and high school. Maximum diversity sampling of sample types was used for the purposes of sample selection. School administrators from different provinces, different positions and different schools have been included to ensure maximum diversity in the sampling. A total of 37 school administrators participated in the study.

In order to conduct this study, ethical committee permission was obtained from the Ethics Committee of Kilis 7 Aralık University (03.06.2020 date, 2020/13 no). The data were collected using a semistructured interview form prepared by the researchers. A total of 6 main questions were in the interview form. The data were collected by researchers in April 2020. The school administrators taking part in the study group have been selected by reaching out to school administrators close to the researchers and other school administrators directed by these school administrators. Descriptive analysis was preferred in the analysis of the data.

\section{Discussion and Results}

In line with the first sub-problem of the research, it was determined that the school administrators had problems within the education system during this period and that these problems were in the form of lack of communication, technical inadequacy, lack of knowledge, teachers' lack of interest and lack of planning. School administrators often stated that they experienced problems due to communication. Communication is an important element in every organization as well as in educational organizations. Since they have students, teachers, parents and other employees, schools are organizations in which communication is experienced in the most intensive way. Schools which are the most important part of the education system are more organized communities compared to the general society (Argon and Zafer, 2009). In such organizations, tasks cannot be carried out without communication at a sufficient level, decisions cannot be applied and therefore objectives cannot be fulfilled (Lunenburg and Ornstein, 2013). Even under normal circumstances, it is inevitable to experience problems in communication (Bayar, 2015; Erol, 1995; Güngör, Altınkaynak, Aksoy, 2018; Güngör and Taşdan, 2016; Koçak, 1991; Nobile, 2014; Şimşek and Altınkurt, 2009) while fighting against a pandemic affecting the entire world in an extraordinary period and facing the limitation of communication channels within the scope of this struggle. In this context, it is very crucial that school administrators use communication channels effectively to reduce communication barriers. Technical incompetence has also been seen as a major problem by school administrators in this study. Accordingly, school administrators have stated that the limited internet availability of teachers, the lack of internet in their regions, and the lack of devices such as tablets and computers by some teachers and students have hindered online education and activities. It is believed that many individuals including students, teachers, school administrators and parents have not been ready for distance education resulting in technical problems. A school administrator has to be involved in every issue that concerns his or her school. Since a school has a complex structure that includes teachers, students, parents and assistant staff, the school administrator should address all of these groups. In other words, school administrators need to make their teachers, students, parents and assistant staff feel that they are supported in this process. It has been concluded that school administrators also have a role in providing motivation for parents and students, sometimes directly through themselves and sometimes through the teachers. For example, informing parents throughout the Covid-19

Turkish Studies, 15(4) 
process and supporting their students both in terms of education and morale is an indication that school administrators are trying to reach out to all sections of the school in a time of crisis.

As a result, it is clear that the worldwide outbreak of Covid-19 has negatively affected the education system as well as other systems. In minimizing this negative impact, school administrators taking the role of a leader have important duties. In particular, the school administrators will have an important effect in terms of ensuring that teachers, students and parents will be motivated and the education activities will be affected at minimum.

Keywords: Education management, Covid-19, School administrator, Education, Problems

Öz: Bu çalışmanın amacı dünya genelinde yaşanan Covid-19 salgınının eğitime etkisini okul yöneticilerinin görüşleri doğrultusunda belirlemektir. Ayrıca okul yöneticilerinin bu süreci nasıl yönettiklerini ortaya koymak da çalışmada amaç olarak belirlenmiştir. Araştırma nitel araştırma türlerinden fenomenolojik desen olarak tasarlanmıştır. Araştırmanın çalışma gurubunu anaokulu, ilkokul, ortaokul ve liselerde görev yapmakta olan 37 okul yöneticisi oluşturmaktadır. Örneklem seçiminde amaçlı örneklem türlerinden maksimum çeşitlilik örneklemesi kullanılmıştır. Veriler araştırmacılar tarafından hazırlanan yarı yapılandırılmış görüşme formu kullanılarak toplanmıştır. Bu çalışma için Kilis 7 Aralık Üniversitesi Etik Kurulundan etik kurul izni alınmıştır. (03.06.2020 tarih ve 2020/13 sayıl1). Veriler 2020 Nisan-Haziran aylarında araştırmacılar tarafından toplanmıştır. Çalışma grubunda yer alan okul yöneticileri, araştırmacılara yakın olan okul yöneticileri ve bu okul yöneticilerinin yönlendirdikleri diğer okul yöneticilerine ulaşılarak belirlenmiştir. Verilerin analizinde betimsel analiz tercih edilmiştir. Araştırmada okul yöneticilerinin Covid-19 süreci kapsamında eğitim sistemi içerisinde sorunlar yaşadıkları ve bu sorunların iletişim eksikliği, teknik yetersizlik, bilgi eksikliği, öğretmenlerin ilgisizliği ve planlama yetersizliği şeklinde olduğu tespit edilmiştir. Araştırmada okul yöneticilerinin öğretmen ve öğrencileri motive ettikleri ve velilere yönelik bilgilendirici faaliyetler gerçekleştirdikleri sonucuna ulaşılmıştır. Öğretmenlere süreçle ilgili aydınlatıcı bilgiler vererek, okula aidiyet duygusunu artırmaya yönelik söylemlerde bulunarak, maddi-manevi desteklerde bulunarak, öğretmenlerle sürekli online iletişim halinde olarak onların sorunlarını, sıkıntılarını dinleyerek, öğretmenlere sürprizler yaparak, bu süreci kolaylaştıracak etkinlik ve seminerler düzenleyerek öğretmenlerinin motivasyonunu artırmaya çalışıkları sonucu elde edilmektedir. Araştırmada okul yöneticilerinin veli ve öğrencilerinin motivasyonunu sağlamada da rollerinin olduğunu bu rolleri bazen doğrudan kendileri aracılığıyla bazen de öğretmenleri vasitasıyla gerçekleştirdikleri sonucuna ulaşılmıştır.

Anahtar Kelimeler: Eğitim yönetimi, Covid-19, Okul yöneticisi, Eğitim, Sorunlar

\section{Giriş}

31 Aralık 2019'da Çin'in Wuhan kentinden bildirilen ve nedeni bilinmeyen zatürre vakalarının kaynağının, hafif enfeksiyonlardan ağır akut solunum sendromlarına kadar ciddi enfeksiyon tabloları oluşturan, büyük bir virüs ailesi olan koronavirüsler olduğu tespit edilmiştir. $\mathrm{Bu}$ aileden, daha önce tespit edilememiş yeni bir koronavirüs türünden kaynaklanan hastalık, Covid-19 olarak tanımlanmaktadır. Hızlı bir şekilde tüm dünyaya yayılan bu hastalığın ülkemizde ilk kez 11 Mart 2020'de saptandığı bilinmektedir (Sağlık Bakanlığı, 2020: 7-11). United Nations Development Programme - UNDP (2020) Covid-19 pandemisinin küresel bir sağlık krizi oluşturduğunu ifade etmektedir. Çok geniş bir coğrafyaya, bir kıtaya ya da zaman zaman tüm dünyaya yayılan, hayvanlarda veya insanlarda hastalık ve ölümlere neden olan bulaşıcı salgın hastalıklar olarak tanımlanan pandemi (Aslan, 2020: 35), yaşam maliyetlerinin artışına ve küresel bir sağlık krizi oluşumuna neden olmaktadır (Ham, 2020: 3).

World Health Organization - WHO (2020: 2) hastaların; tespit ve izole edilmesinin, temaslarının izlenmesi ve karantina altına alınmasının, yapacakları uluslararası seyahatlere sinırlama getirilmesinin yanında bireylerin sosyal hayattan ve fiziksel temastan uzaklaşmasının da enfeksiyon sayısını azaltmada ve hayat kurtarmada önemli bir etken olduğunu ifade etmektedir. UNDP (2020) birçok ülkenin bu etkenleri kontrol altına almak için büyük mücadeleler verdiğini belirtmektedir. Bu kapsamda dünya genelinde ekonomik, sağlık, sosyal, eğitim gibi birçok alanda 
önleyici faaliyetler uygulanmaya başlanmıştır. Özellikle geniş bir kitleyi etkileyen eğitim alanında öncelikli olarak önlemler alınıp uygulanmıştır. Bu kapsamda okulların eğitime ara vermesi kararı dünyadaki öğrenci nüfusunun \%90'ından fazlasını etkisi altına almıştır (United Nations Educational, Scientific and Cultural Organization- UNECSO, 2020). Viner, Russell, Croker, Packer, Ward, Stansfield, Mytton, Bonell ve Booy (2020: 402) bu önlemlerin çok uzun süre alınması gerekebileceğine dair öngörüler olduğunu ve öğrencilerin eğitime güvenli bir şekilde devam edebilmelerine yönelik yöntemlerin hızlı bir şekilde belirlenmesi gerektiğini ifade etmektedirler. Bu kapsamda birçok ülke uzaktan eğitim faaliyetlerini yürütmektedir. Öğretmen ve öğrencilerin farklı mekânlarda aynı veya farklı zamanlarda iletişim kurmalarıyla gerçekleştirilen uzaktan eğitim (Odabaş, 2003: 24) ülkemizde de internet ve televizyon aracılığıyla verilmektedir. $\mathrm{Bu}$ durum eğitim sürecinde farklılık olarak algılansa da birçok sorunu da beraberinde getirmektedir.

Eğitim süresince yaşanan değişimler okul müdürlerinin geleneksel idareci rollerini, çağc1l bir eğitim lideri olmaları yönünde zorlamaktadır (Aras, 2020: 1). Bilgi yönetiminin çok önemli olduğu günümüzde bilgi çağı örgütlerinin, teknoloji ve insanı bir araya getirerek bilgiyi kullanması ve yönetmesi örgütün temel faaliyetleri arasında yer almaktadır. Bu kapsamda özellikle bilginin öncelikli kabul edildiği kurumlarda görev yapanlar, öğrenme ve gelişimlerini sağlamak için teşvik edilmekte ve kurumda öğrenmeyi sürekli hale getirecek ortamlar yaratılmaktadır (Atak ve Atik, 2007: 64). Eğitim sisteminde okulların temel görevi, öğrencilere istendik davranışları kazandırmak ve belirli öğrenme yaşantılarının öğrencilerle yaşanmasını sağlamak amacıyla çevreyi gerekli biçimde düzenlemektir. Toplumun sosyal ve ekonomik değişimleri, okulda çalışanların düşünüş ve davranış biçimlerini değiştirmelerini zorunlu kılmaktadır (Gökyer ve Naml1, 2015). Okul yöneticisi ve personelleri bu gelişmelerin öncüsü ve gerekli kıldığ 1 yeniliklerin uygulayıcısı olmak durumundadir (Taymaz, 2019:4).

Günümüz değişim dünyasında okul yöneticilerinin eğitimci liderliği tek başına yeterli olmamakta ve bunun yanı sıra değişime açık olma ve değişim liderliği konularında da duyarlı olmaları gerekmektedir (Fullan, 2002: 16). Thompson (1994)'e göre okul müdürleri değişimi etkili bir şekilde yönetmek adına değişimden etkilenecekleri değişim sürecinin her aşamasında bilgilendirmeli, örgütü ve çalışanları bekleyen güçlükleri önceden bildirmeli, olası problemlere karşı hazırlıklı olmalıdır (Çelikten, 2006). Bu süreçte sergilenen liderlik davranışları, çalışanlara rehberlik ve desteğin yanında çalışanların motivasyonunu da sağlamaktadır (Demir, 2019: 8). Öğretmenler de okul müdürlerinin davranışlarını, motivasyonlarını etkileyen bir unsur olarak görmektedir. Ayrıca veliler ve diğer okul paydaşları da okul müdürlerinin yönetsel davranışlarını takip etmektedirler (Okumuş, 2017: 2). Akbaba (2020: 142) okulun, liderin sergilediği liderlik becerileri oranında büyüdüğünü ve başarılı olduğunu ayrıca etkili lidere sahip okulların, etkili ve kaliteli eğitim kurumları olduğunu ifade etmektedir.

$\mathrm{Bu}$ araştırmada eğitim öğretimin esas durakları olan okulların işleyişine yön veren okul yöneticilerinin; Covid-19 sürecinde uzaktan eğitimle ilgili yaşadıkları problemleri, öğretmenler ile öğrencileri motive etmede ve velileri bilinçlendirmede kullandıkları yöntemleri kendi bakış açıları üzerinden tespit etmek amaçlanmaktadır. Araştırma, Covid-19 salgın hastalığı ile başlayan uzaktan eğitim sürecindeki aksaklıkların ve kullanılan etkili yöntemlerin tespiti ve değerlendirilmesinin yapılması ve bu konuda uygulayıcılara yol göstermesi adına önem arz etmektedir. Bu kapsamda aşağıdaki sorulara cevap aranmıştır: nelerdir?

Okul yöneticilerinin görüşüne göre Covid-19 sürecinde eğitim ile ilgili yaşanan problemler

Okul yöneticileri Covid-19 sürecinde öğretmenlerinin motivasyonunu nasıl sağlamaktadırlar? 
Okul yöneticilerinin Covid-19 sürecinde öğrencilerin motivasyonunu sağlamada kullandıkları yöntemler nelerdir?

Okul yöneticilerinin Covid-19 sürecinde öğrenci velilerinin bilinçlendirilmesi için yapmış oldukları etkinlikler nelerdir?

\section{Yöntem}

Araştırmada okul yöneticilerinin Covid-19 sürecinin eğitime yansımasına yönelik görüşlerini derinlemesine açıklamaya imkan sağladığı için nitel araştırma yöntemi tercih edilmiştir. Araştırma nitel araştırma türlerinden fenomenolojik desen olarak tasarlanmıştır. Fenomenolojik desen, bireylerin kendi bakış açılarına göre algı ve deneyimlerini ön plana çıkarmayı amaçlayan bir nitel araştırma desenidir (Ersoy, 2016). Bu desende çalışma grubuna dahil olan katılımcıların doğrudan deneyimlere sahip olması önemli olarak görülmektedir (Patton, 2014: 104). Bu çalışmada da dünya genelinde etkisini süren Covid-19'un eğitim sistemine etkisini bu süreci birebir deneyimleyerek yöneten okul yöneticilerinin görüşleri doğrultusunda irdelemek amaçlandığından fenomenolojik desen kullanılmıştır.

\section{Çalışma Grubu}

Araştırmanın çalışma gurubunu anaokulu, ilkokul, ortaokul ve liselerde görev yapmakta olan okul yöneticileri oluşturmaktadır. Örneklem seçiminde amaçlı örneklem türlerinden maksimum çeşitlilik örneklemesi kullanılmıştır. Bu yöntemin kullanılmasının amacı, küçük bir örneklem grubu içerisinde probleme taraf olabilecek bireylerin çeşitliliğini maksimum seviyede yansıtmaktır (Yıldırım ve Şimşek, 2018). Maksimum çeşitliliğinin sağlanması için farklı okul kademelerinden farklı pozisyondan, farklı illerden okul yöneticileri örnekleme dâhil edilmiştir. Araştırmaya toplamda 37 okul yöneticisi katılmıştır. Katılımcılara ait kişiler bilgiler Tablo 1'de verilmektedir.

Tablo 1: Okul Yöneticilerin Ait Demografik Bilgiler

\begin{tabular}{lll}
\hline Değişken & Grup & f \\
\hline Cinsiyet & Kadın & 6 \\
& Erkek & 31 \\
\hline Pozisyon & Müdür Yardımcısı & 12 \\
& Müdür & 25 \\
\hline Okul Türü & Anaokulu & 5 \\
& İlkokul & 10 \\
& Ortaokul & 8 \\
& Lise & 14 \\
\hline Okulun bulunduğu il & Kilis & 24 \\
& Hatay & 13 \\
\hline Toplam & & 37 \\
\hline
\end{tabular}

Tablo 1 incelendiğinde görüşmeye dahil olan okul yöneticilerinin 6'sının kadın, 31'inin erkek; 12'sinin müdür yardımcıs1, 25'inin müdür olduğu ve 24 okul yöneticisinin Kilis ilinde, 13 okul yöneticisinin ise Hatay ilinde görev yaptığ 1 görülmektedir. 5'i anaokulunda, 10'u ilkokulda, 8'i ortaokulda ve 14'ü lisede görev yapan okul yöneticilerine ulaşılmıştır.

\section{Verilerin Toplanması}

Bu çalışma için Kilis 7 Aralık Üniversitesi Etik Kurulundan etik kurul izni alınmıştır. (03.06.2020 tarih ve 2020/13 sayıl1). Araştırmacılar tarafından hazırlanan yarı yapılandırılmış görüşme formu kullanılarak veriler toplanmıştır. Görüşme formu hazırlanırken öncelikle araştırmacıların çevrelerindeki okul yöneticileri ile içinde yaşanılan süreç dikkate alınarak ön görüşmeler yapılmıştır. Farklı okul türünde görev yapan okul yöneticileri ile yapılan görüşmeler sonucunda 8 adet görüşme sorusu hazırlanmıştır. Görüşme soruları hazırlandıktan sonra eğitim 
yönetimi alanında doktorasını tamamlamış iki öğretim üyesinden uzman görüşü alınmıştır. Uzmanlardan gelen dönütler doğrultusunda aynı cevaba yol açan 2 soru görüşme formundan çıkarılmıştır. Soruların anlaşılabilirliğini ölçmek amacıyla bir okul müdürü bir de okul müdür yardımcısı ile pilot uygulama yapılmıştır. Pilot uygulamada soruların anlaşılabilirliğine dair olumsuz bir dönüt gelmediği tespit edilerek görüşme formunun son haline karar verilmiş ve asıl uygulamaya geçilmiştir. Görüşme formunda 6 ana soru yer almaktadır. Görüşme formunda şu şekilde sorular yer almaktadır: misiniz?

Karantina döneminde öğretmenlerinizle nasıl bir iletişim ağı oluşturdunuz? Açıklayabilir

Karantina döneminde öğretmenlerinizi motive etme konusunda ne tür çalışmalarınız oldu? Açıklayabilir misiniz?

Veriler 2020 Nisan-Haziran aylarında araştırmacılar tarafından toplanmıştır. Çalışma grubunda yer alacak okul yöneticileri, araştırmacılara yakın olan okul yöneticileri ve bu okul yöneticilerinin yönlendirdikleri diğer okul yöneticilerine ulaşılarak belirlenmiştir. Çalışma grubu belirlendikten sonra iletişim sorunları veya yoğunluktan ötürü 12 okul yöneticisinden görüşme formunu doldurmaları suretiyle veriler alınmıştır. 12 okul yöneticisine mail yoluyla görüşme formu ulaştırılmış, bir iki gün içerisinde geri dönütler sağlanmıştır. 25 okul yöneticisi ile de karantina sürecinden dolayı sesli veya görüntülü telefon görüşmeleri ile veriler toplanmıştır. Görüşmeler araştırmacılara ve okul yöneticilerine uygun olan zaman diliminde planlanarak geçekleştirilmiştir. Yapılan görüşmeler yaklaşık 30 dakika sürmüştür. Sesli veya görüntülü görüşmeler yapıldıktan sonra veriler yazıya dökülmüş ve görüşlerini teyit ettirmek amacıyla katılımcılara gönderilmiş, geri dönütler alınmıştır.

\section{Veri Analizi}

Verilerin analizinde betimsel analiz tercih edilmiştir. Betimsel analizde toplanan veriler çalışmanın araştırma problemi ile bağlantılı olarak nelerin söylendiği ya da ne tür sonuçların ortaya konulduğunu belirlenmektedir (Yıldırım ve Şimşek, 2018). Görüşme formunda yer alan sorular dikkate alınarak kategoriler belirlenmiştir. Araştırmanın bulgularında her bir katılımcıya belli bir kod verilerek görüşleri açıklanmıştır (K1, K2, 1. Kişi, 2. Kişişseklinde).

Araştırmanın geçerlik ve güvenirliğini sağlamaya yönelik çalışmalar yapılmıştır. Görüşme formu hazırlanırken uzman görüşü alınarak kapsam geçerliği sağlanmıştır. Görüşmeler yapıldıktan sonra katılımcılara görüşlerinin yer aldığ1 formlar gönderilip bilgilerin kendilerine ait olup olmadığı ve ifade etmek istediklerini yansıtıp yansıtmadığına dair dönütler alınmıştır. Verilerin analizinde kodlamalar iki farklı araştırmacı tarafından yapılıp karşılaştırılmıştır, böylece çalışmanın güvenirliği sağlanmıştır. Ayrıca çalışma sürecinin nasıl yürütüldüğü hakkında detaylı bilgiler vererek ve katılımcılara ait görüşlere sıklıkla yer verilerek çalışmanın güvenirliğini artırmak amaçlanmıştır.

\section{Bulgular}

Araştırmanın birinci problemi doğrultusunda, okul yöneticilerinin Covid-19 sürecinde eğitim süreci ile ilgili yaşadıkları sorunlar belirlenmiştir. Okul yöneticilerinin görüşleri doğrultusunda yaşanılan sorunlar Tablo 2'de yer almaktadır. 
Tablo 2: Okul Yöneticilerinin Görüşlerine Göre Eğitim Sürecinde Yaşanılan Sorunlar

\begin{tabular}{lll}
\hline Kategoriler & Kat1lımc1lar & Frekans \\
\hline İletişim eksikliği & K1, K3, K6, K7, K9, K13, K16, K17, & 15 \\
& K18, K22, K23, K25, K28, K31, K35 & \\
\hline Teknik yetersizlik & K2, K7, K9, K12, K14, K20, K25, & 11 \\
& K27, K30, K36, K37 & \\
\hline Bilgi eksikliği & K11, K12, K15, K19, K26, K27, K30, & 8 \\
& K36 & \\
\hline Öğretmen ilgisizliği & K8, K13, K19, K29 & 4 \\
\hline Planlama yetersizliği & K34 & \\
\hline
\end{tabular}

Tablo 2'de okul yöneticilerin Covid-19 sürecinde eğitim adına yaşadıkları sorunlar görülmektedir. Görüşme yapılan 7 okul yöneticisi bu süreçte herhangi bir sorun yaşamadığını ve her şeyin kontrolleri altında gerçekleştiğini ifade etmişlerdir. 30 okul yöneticisi ise işleyişte sorunlar yaşadıklarını belirtmişlerdir. Görüşmeye katılan okul yöneticilerinin hepsi pandemi sürecinde öğretmenlerle resmi olarak sosyal medya hesapları üzerinden iletişim kurduklarını ve öğretmenlerle haftalık online toplantılar yaptıklarını belirtmişlerdir. Ancak bu iletişim ağlarını kurarken de bazı problemlerle karşılaştıklarını ifade etmişlerdir. Okul yöneticilerinin büyük çoğunluğu gerek öğretmenlerle gerek öğrencilerle gerekse de velilerle iletişim eksikliğine (15) bağglı olarak sorun yaşadıklarını dile getirmişlerdir. Bu konu ile bir katılımc1; "Yazılı olarak iletişime geçtiğimiz için iletişimde kopukluklar yaşadık, tam anlaşılamama ve yapılacak konu ile ilgili ögretmenler tarafindan geç dönüşler oldu. (K13)" şeklinde görüş bildirmiştir. Bir başka katılımc1 "Geri dönütlerde sorunlar yaşadık. Bilgilerin hepsini hemen ögrretmenlere ulaştırmada slkıntılar yaşadık. (K18)" açıklamasında bulunmuștur. K25 kodlu katılımcı ise "Yüz yüze iletişim olmadı̆̆ için aksaklıklar meydana geldi. Aradı̆̆ımız zaman müsait değilse ulaşamadık. Toplantıda internet koptuğunda öğretmenle iletişimimiz de kesilmiş oluyor" diyerek iletişimden kaynaklı yaşadığ1 sorunları açıklamıştır. K35 kodlu katılımc1 ise okulun bulunduğu bölgeye bağlı olarak "İletişim kurmak çeşitli araç gereçlerle sağlandı̆̆ından dolayı bunların sıkıntıları oldu. Bulunduğumuz bölgeden dolayı veli ve ögrencilerimizle iletişim kurmakta sıkıntılar yaşadık, şebeke problemi ve internete erişim sağlanamaması gibi." şeklinde açıklamada bulunmuştur. Genel anlamda görüşmeye katılan okul yöneticilerinin öğretmenlerle iletişim kurma konusunda sorunlar yaşadıkları bu sorunların online veya yüz yüze olmayan iletişim yollarını kullanmalarından ve geri dönütlerin yeterli olmamasından kaynaklandığı söylenebilir.

Okul yöneticilerin en fazla yaşadıklanı diğer bir sorun ise teknik yetersizliktir. Bu konu ile ilgili 11 okul yöneticisi sorun yaşadıklarını bildirmişlerdir. Bir okul yöneticisi "EBA sisteminde yoğunluktan ötürü ögrenci ve ögretmenlerimiz girişte zorluk yaşadılar. (K11)" şeklinde sıkınt1 yaşadığını ifade etmiştir. K27 kodlu okul yöneticisi "Teknoloji kullanımı konusunda sorunlar yaşadık ve uzaktan eğitimin altyapısının kötü ve kullanışsız olmasıyla ilgili sorunlar yaşadık” diye görüşünü bildirmiştir. Başka bir okul yöneticisi ise "Internette yaşanan yoğunluktan ya da ögretmenin internete erişimi ile ilgili problemlerden kaynakl yönlendirme ile ilgili sikıntılar yaşanmıştır (K37)" açıklamasında bulunmuştur. Teknik yetersizlik konusunda yaşanan sorunlar genel anlamda ele alındığında uzaktan eğitim sisteminde yaşanan problemlerin olduğu ve öğretmen ve öğrencilerin internete erişimlerinin sınırlı olduğu söylenebilir.

Görüşme yapılan okul yöneticilerinden 8 katılımcı bilgi eksikliğine bağlı olarak sorunlar yaşadıklarını belirtmişlerdir. Öğretmenlerin uzaktan eğitim ile ilgili donanımlara sahip olmadığını belirten K12 kodlu katılıme "Öğretmenlerimizin web araçlarını kullanma ve uzaktan eğitim programlarına karşı yetersiz seviyede olmalar nedeniyle kullanım bilgilendirme faaliyetlerinde sıkıntı yaşadık" açıklamasında bulunmuştur. Öğrencinin bilgi eksikliğine vurgu yapan K30 kodlu katılımc1 ise "Özellikle ilkokul ögrencilerinin teknolojiyi kullanma anlamında yaşça kü̧̈ük olmaları, EBA sistemini bilmemeleri ve kullanamama anlamında sıkıntılar yaşıyoruz" şeklinde görüşünü bildirmiştir. Yine EBA sistemi ile ilgili bir başka katılımcı da "EBA sisteminin görece 
yeni olması sebebiyle ögretmenlerimizin bu konuda çok fazla bilgiye sahip olmamaları adaptasyon süreçlerinin öngörülenden biraz fazla zaman aldığını söylemek yerinde olacaktır (K36)" açıklamasında bulunmuştur. Okul yöneticilerinin görüşleri dikkate alındığında genel anlamda hem öğrenci hem de öğretmenlerin uzaktan eğitim sistemi ile ilgili bilgi eksikliğine bağlı olarak sorunlar yaşadıkları söylenebilir.

4 okul yöneticisi öğretmenlerin ilgisiz olmasını Covid-19 sürecinde yaşadıkları sorunlardan biri olarak belirtmişlerdir. Bu konu ile ilgili bir okul yöneticisi “Öğretmenlerimizi EBA programına yönlendirirken EBA'da yer alan mesleki gelişim videolarından yararlanmak yerine kulaktan dolma bilgilerle hareket etmeleri ve neticede yanlış işler yapmalarından dolayı problemler yaşadık (K19)" açıklamasında bulunmuştur. K8 kodlu katılımcı ise "Bazı öğretmenlerimiz bu süreci bir tatil olarak düşünüyorlar, uzaktan eğitime odaklanmıyorlar, toplantılara katılmak bile istemiyorlar" şeklinde görüş bildirmiştir. Bir başka katılımc1 ise "Süreci tatil olarak algilayan öğretmenlerimiz var. Öğrencilere duyurulması gereken bir iş verdiğimizde çok isteksiz davranıyorlar ve genelde internetimiz sinırl ya da ögrencilere ulaşamıyoruz şeklinde bahaneler üretiyorlar (K29) " diye yaşadığı sorunu ifade etmiştir.

Son olarak bir okul yöneticisi bu süreç içerisinde planlama konusunda yaşadığı problemi "Karantina döneminin ilk günlerinde neleri yapıp neleri yapamayacă̆ımızı planlamakta zorluk çektik. Öğrenciler ve ögretmenlerden dersler, sinavlar vs. konularda siklıkla sorular geliyordu ve biz önümüzü göremiyorduk. (K34)” şeklinde açıklamıştır.

Araştırmanın ikinci problemi doğrultusunda "Okul yöneticileri Covid-19 sürecinde öğretmenlerinin motivasyonunu nasıl sağlamaktadırlar?" sorusuna cevap aranmıştır. Görüşme yapılan okul yöneticilerinin hepsi öğretmenlerin motivasyon konusunda desteğe ihtiyaçlarının olduğunun farkında olduklarını ve bu konuda öğretmenlerine destek olduklarını belirtmişlerdir. Okul yöneticilerinin öğretmenlerini motive etmede uyguladıkları yöntemlere ilişkin bazı görüşler aşağıda sıralanmıştır:

"Bireysel olarak her zaman iletişim halindeyiz, Vefa gurubunda yer allyoruz, aslında bir nevi hayatın devam edeceğine olan inancımızı aşıllyoruz (K3)”"

"Bu süreçte zorlanmasınlar diye işlerini kolaylaştırmaya çallşılyorum, öğrenci velilerine ulaşmalarına yardım ediyorum, ulaşamayacaklarını düşündügü̈m dokümanları hemen ögretmenlerimle paylaşıyorum. (K4)"

"Tüm ögretmenlerimizin okulumuz için ne kadar önemli olduğunu her toplantıda isim isim belirterek söylüyorum. (K11)"

"Öğretmenlerimizle ara ara güzel günleri göreceğimize dair müzikler ve videolar paylaşlyorum. (K12)”

"Okul ile bağlarının daha sıcak kalması için okulumuzdan fotoğraf kareleri gönderiyorum. Bu yıl öğretmenlerimiz ile yaptığımız güzel aktiviteleri paylaşarak güzel günlerin tekrar geleceği üzerinde duruyorum. (K13)"

"Öğretmenlerimize online olarak doğum günü kutlaması vs. etkinlikler ve sağlıkl yaşama ve spor konulu seminerler düzenledik. (K14)”

“Tüm ögretmenlerimize ve personelimize karantina sürecinde maddi-manevi destek olmak amacıyla hemen hepsini telefonla arayarak herhangi bir ihtiyaçlarının olup olmadığını sürekli kontrol etmekteyiz. Bu iletişim sürecinin ögretmen-idareci-personel özelinde kurumumuz açısından olumlu dönütler getireceğini düşünmekteyiz. (K19)"

"Öğretmenlerle bir grup öğrencimizin hazırladiğı video paylaşımı ile moral ve motivasyonu artırdığımızı düşünüyorum. (K22)” 
"Sürpriz mesajlar atıyoruz, doğum günleri gibi özel günlerini kutluyoruz. (K23)"

"Kararları beraber verdik böylece yüksek motivasyonla başladık. Uygulama konusunda her türlü teknik aksaklı̆̆a yardım edeceğimizi sadece uygulamaya koyulmalarl gerektĭgini bu durumda yapılan hataların üstüne çok gitmeyeceğimizi söyledik. (K27)"”

"Bakanlığın hazırlamış olduğu Koronavirüs ile mücadelede gençler için psikolojik destek rehberlerini, bakanımızın konuşmalarından özet kısımları firsat buldukça öğretmenlerimiz ve çalışanlarımızla paylaştık. Yine aynı şekilde bakanlı̆̆ın yayımladı̆̆ "Aileler için Çocuklara Yardım", "Yetişkinler için Bilgilendirme Rehberi" gibi psikoloji koruma rehberlerini paylaştık. (K30)"

"Okulla ilgili yaptığımız çalışmaları web sitesi ve okul whatsapp grubunda paylaştık. Öğrencilerin okul ve ögretmenleriyle ilgili yapmış oldukları resimleri video haline getirip okul grubunda paylaştık. (K34)"

"Resmi işlerden bağımsız olarak; karantina sürecinde ilimizde ikametlerini sürdüren ve özellikle şahsi aracı olmayan tüm arkadaşlarımızı okul idaresi olarak hemen her gün telefonla arayarak onların ihtiyaçlarının olup olmadığ konusunda bilgi alışverişinde bulunmaktayız. Ayrıca hemen her duyuru mesajımızın sonuna "güzel günlerde görüşmek dileklerimizle" tarzında kısa notlar ekleyerek onları motive etmeye çalışıyoruz. (K36)"

"Hastalığın ciddiyeti hatırlatılmak ile birlikte evde kalmaları ve sosyal mesafe kurallarına dikkat etmeleri hatırlatılmakta bununla birlikte her şeyin en kisa sürede normale döneceği konusunda moral verici konuşmalar yapılmaktadır. (K37)"

Okul yöneticilerin görüşleri incelendiğinde genel anlamda süreç esnasında bilgilendirmeler yaparak, okula aidiyet duygusunu artırmaya yönelik söylemlerde bulunarak, maddi-manevi desteklerde bulunarak, bugünlerin geçici olduğunu daha güzel günler göreceğimize dair teminat vererek, öğretmenlerle sürekli online iletişim halinde olarak onların sorunlarını, sıkıntılarını dinleyerek, öğretmenlere sürprizler yaparak, bu süreci kolaylaştıracak etkinlik ve seminerler düzenleyerek öğretmenlerinin motivasyonunu artırmaya çalıştıkları görülmektedir.

Araştırmanın üçüncü problemi doğrultusunda "Okul yöneticilerinin Covid-19 sürecinde öğrencilerin motivasyonunu sağlamada kullandıkları yöntemler nelerdir?" sorusuna cevap aranmıştır. Bu konu ile ilgili okul yöneticilerinden gelen görüşler şu şekildedir:

"Sormak istedikleri bir soru ya da anlayamadıkları bir konu olduğunda EBA üzerinden hem arkadaşlarına hem de ögretmenlerine ulaşabilecekleri ve karantina süreci sona erip okula geri döndüğümüzde telafiler yapılacağı onlara en ince ayrıntısıyla paylaşıldl. Gayrette olsunlar ve panik yapmasinlar diye telkinde bulunuldu. (K2)"

"Görsel olarak okul idaresi ve tüm ögretmenler tarafindan hazırlanan, üzerinde ögrencilere sağllk ile ilgili mesaj olan, tüm ögrretmenlerin resimlerinin olduğu resimli afiş gönderildi. (K6)"

"Karantina sürecinde sıklmamaları için oyun merkezli etkinlik örnekleri verildi ve gün sonunda görselleri istendi. (K8)" (K9)”

"Öğrencileri motive etmede ögretmenlerimiz aktif rol oynadılar, biz onları yönlendirdik.

"Bir okul müdürü olarak kendime bir hedef koydum. Bu süreç başladığı haftadan itibaren her gün iki öğrenciyi arayıp hal hatır soruyorum, çok şaşırtyorlar benim sesimi duyunca, ama çok da mutlu oluyorlar. (K10)" 
"Öğrencilerimizi motive etmek için okulumuzun sosyal medya hesaplarından çocukların evde aileleriyle yaptıkları etkinlikleri günlük paylaşılmıştır. Zira okulun kendisini paylaştığını gören çocuk daha çok etkinliklere katılım sağlamak isteyerek motivasyonu artmıştır. (K11)”

"Köy okulu olmamıza rağmen öğretmenlerimiz kendi sinıfları için whatsapp grupları oluşturduk. Bu gruplarda ögretmenlerimiz tarafindan ögrencilere gerek eğitim gerekse motivasyon arttırma yönünde güzel etkinlikler paylaşıldı. (K14)"

"Öğrencilerimize ulaşarak onların herhangi bir ihtiyaçlarının olup olmadĭ̆ını öğrendik. Öğrenciler dersler noktasında endişeliydi. Bakanlığımızın bu konuda özveriyle çalışı̆ı̆̆ın EBA TV üzerinden derslerin takip edilmesi gerektiğini ögretmenlerinin gönderdiği çalışmalar yaparak bu durumun üstesinden geleceklerini söyledik. (K16)"

"Karantina döneminde okul idaresi ve ögretmenler olarak öğrenciler ile gerek görüntülü gerekse sesli olarak görüşmeler yaparak bu sürecin geçici olduğunu bunun bir tatil değil eğitim süreci olduğunu ve bu süreci en iyi şekilde değerlendirmemiz gerektiğini belirtiyoruz. (K20)"

"Sinava hazırlık aşamasında olan ögrencilerimize özel gruplar oluşturduk, belli bir program dâhilinde rehber ögretmeni eşliğinde çallşmalarını takibe aldık. (K21)"

“Öğrencilerimize sık sık bunun bir tatil olmadığını aslında bunun zorunlu bir ihtiyaçtan kaynaklandĭ̆ını anlattık. Özelliklede bu tür durumlarda, insanlığın çaresiz kaldiğı durumlarda çalışan, bilime merak duyan, araştıran bireylere ihtiyaç olduğunu ve bunlardan bir tanesinin neden kendilerinin olamayacağını dile getirmeye çalıştık. (K30)"

"Öğrencilerin il ve bakanlık düzeyindeki yarlşmalara öğretmen ve idareciler tarafindan imkânlar dâhilinde katılımları sağlandı. (K31)" (K34)"

"Öğrencilerin kendilerini anlatan ilginç karantina anılarını okul grubunda paylaştık.

Görüşler ele alındığında okul yöneticilerinin öğretmenler aracılığı ile öğrencileri motive ettikleri görülmektedir. Öğrencilerin bu zorlu süreci rahat bir şekilde atlatabilmeleri için onların yanında olduklarına dair mesajlar ilettikleri, ders konusunda destek oldukları, sosyal medya üzerinden eğlendirici etkinliklere dâhil ettikleri ve her şeyin geçici olduğu ve bu sürecin biteceğine dair telkinlerde bulundukları tespit edilmiştir.

$\mathrm{Bu}$ süreç kapsamında öğretmen ve öğrenciler kadar veliler de ön plana çıkmaktadır. Bir anda ebeveynlik haricinde evde çocuklarının eğitimini takip etme durumu ile karşı karşıya kalmışlardır. Bu sebeple araştırmanın dördüncü problemi "Okul yöneticilerinin Covid-19 sürecinde öğrenci velilerinin bilinçlendirilmesi için yapmış oldukları etkinlikler nelerdir?" şeklinde belirlenmiştir. $\mathrm{Bu}$ kapsamında okul yöneticileri tarafından yapılan etkinliklere ait görüşler aşağıda verilmiştir:

"Kurumsal SMS sistemiyle bilgilendirmeler yapıldı. (K4)"

"Velilere EBA'ya nasıl girileceği konusunda el broşürleri gönderdik. (K5)",

"Öğretmenlerimiz tarafindan her sınıf için oluşturulan whatsapp gruplarından sürekli olarak velilerimize, kendilerinin ve çocukların bu olaylardan olumsuz etkilenmemeleri ile ilgili olarak neler yapmaları gerektiği, onlarla nasıl verimli vakit geçirmeleri gerektiği ile ilgili görsel, yazılı ve ihtiyaç olduğunda da özel konuşarak rehberlik çalışmaları yapıldl. (K6)"

"Velilerimiz için Covid-19 ve uzaktan eğitim ile ilgili bilgilendirme broşürleri ve çalışmalar okul web sayfamız, okul sosyal medya hesapları üzerinden de ulaşılabilecek şekilde düzenli aralıklarla paylaşılmaktadır. (K9)" 
"Bakanlı̆̆ımızın velilerimize ulaştırılması istenilen tüm çalışmalar velilerimize sosyal medya üzerinden ulaştırılmaya çalışılmıştır. Ayrıca bu konuda ögrretmenlerimizle beraber haftalık etkinlikler planlayarak velilere gönderilmiş ve evde çocuklarıyla beraber yapmaları sağlanmıştır. (K11)”

"Covid-19 ile ilgili broşürleri ve bilgilendirici metinleri whatsapp aracılı̆̆gyla velilerimiz ile buluşturduk Öğretmenlerimiz EBA üzerinden hijyen ve doğru el ylkama üzerine videolar paylaştı. (K13)",

"Öğretmenlerimizle birlikte velilerimizi tek tek arayarak öğrencilerimizin bizim için değgrli olduğunu ĕgitim öğretimin aksamaması gerektiğini belirterek velilerimize ellerinde geldiğince gerekli alt yapıyı sağlamaları gerektiğini, telefonlarına internet sağlamaları gerektiğini ve televizyonlarına EBA TV'yi kurmaların söyledik, kuramayanlara yardımcı olduk. (K20)"

"Okulumuzun web sitesinden Covid-19 hastaliğ ile ilgili dikkat edilmesi gereken hususlara yönelik hazırlanmış olan broşürler ve Veli Bilgi Notu yayınlanmış ayrıca sağllk bakanlığ Covid-19 ile ilgili ayrıntıl bilgilere ulaşabileceği yönlendirme linki eklenmiștir. Velilerimiz mesaj sistemi ile de bilgilendirilmektedir. (K37)"

Okul yöneticilerinin görüşleri dikkate alındığında sosyal medya grupları, kurumsal mesajlar, telefon, broşür gibi iletişim ağları kullanarak velilere ulaşmaya çalıştıkları ve gerek kendileri gerekse öğretmenleri aracılığı ile velilere Covid-19 ve uzaktan eğitim konusunda bilgilendirme yaptıkları sonucuna ulaşılmıştır.

\section{Sonuç ve Tartışma}

$\mathrm{Bu}$ çalışmanın amacı dünya genelinde yaşanan Covid-19 salgınının eğitime etkisini okul yöneticilerinin görüşleri doğrultusunda belirlemektir. Ayrıca okul yöneticilerinin bu süreci nasıl yönettiklerini ortaya koymak da çalışmada amaç olarak belirlenmiştir. Bu bölümde araştırmada elde edilen sonuçlar ortaya konulup alanyazında yapılan çalışmalarla kıyaslanarak tartışılmıştır.

Araştırmada okul yöneticilerinin bu süre kapsamında eğitim sistemi içerisinde sorunlar yaşadıkları ve bu sorunların iletişim eksikliği, teknik yetersizlik, bilgi eksikliği, öğretmenlerin ilgisizliği ve planlama yetersizliği şeklinde olduğu tespit edilmiştir. Okul yöneticileri çoğunlukla iletişimden kaynaklı sorunlar yaşadıklarını belirtmişlerdir. Her örgütte olduğu kadar eğitim örgütlerinde de iletişim önemli bir unsurdur. Öğrencisi, öğretmeni, velisi ve diğer çalışanları olması itibari ile okullar iletişimin en yoğun olarak yaşandığı örgütlerdir. Okullar eğitim sisteminin en önemli parçası olmakla beraber içinde yaşadığ 1 topluma göre daha düzenli ve planlı olarak örgütlenmiş toplumlardır (Argon ve Zafer, 2009). Bu tarz örgütlerde yeterli düzeyde iletişim olmadan görevler yerine getirilemez, kararlar uygulanamaz ve dolayısıyla amaçlara ulaşılamaz (Lunenburg ve Ornstein, 2013). Normal şartlar altında dahi genelde örgütlerde özelde ise okullarda sıklıkla iletişim engellerini yaşanılıyorken (Bayar, 2015; Erol, 1995; Güngör, Altınkaynak, Aksoy, 2018; Güngör ve Taşdan, 2016; Koçak, 1991; Nobile, 2015; Şimşek ve Altınkurt, 2009) olağanüstü süreç içerisinde tüm dünya genelini etkisi altına alan bir salgınla mücadele ederken ve bu mücadele kapsamında iletişim kanallarının sınırlandırılması ile karşı karşıya kalınmışken, iletişimde sorunlar yaşanılması kaçınılmazdır. Bu bağlamda okul yöneticilerinin iletişim engellerini azaltacak iletişim kanallarını etkili bir şekilde kullanması oldukça önem arz etmektedir.

Covid-19 süreci ile birlikte dünyada ve Türkiye'de eğitimlere ara verilmiş ve eğitim öğretim uzaktan eğitim yöntemi ile gerçekleştirilmiştir. Küreselleşmenin getirdiği zorunluluklardan biri de uzaktan eğitimdir. Uzaktan eğitim; öğrenen ile öğreticilerin farklı yer ve zamanlarda bulunduğu ve aralarındaki etkileşimin elektronik iletişim araçları ile gerçekleştiği bir öğretim biçimidir (Aydın, 2005). Uzaktan eğitimin aynı anda birçok kişiye ulaşılması, öğrencilerin öz değerlendirme yapmalarına imkân sağlaması, eşzamanlı ve eşzamansız öğrenme alternatifleri sunması, zamandan tasarruf sağlaması, erişilebilirliğinin kolay olması (Begimbetova, 2015; Duran, 
Önal ve Kurtuluş, 2006; Özlü, 2011; Seven, 2012; Tuncer ve Taşpınar, 2008) gibi birçok avantajını saymak mümkündür. Avantajlarının yanında uzaktan eğitimle ilgili sorunların olduğuna yönelik araştırmalar da mevcuttur. Uzaktan eğitimle ilgili sorunlar yüz yüze etkileşimin olmamasından dolayı öğrenen ile öğretici arasında etkileşimin düşük olması, geribildirimin yetersiz olması, deneyim eksikliği, teknik aksaklıklar, beceri ve tutum geliştirmede yetersiz olması (Bilgiç ve Tüzün, 2015; Bonk, 2001; Chen ve Wang, 2008; Falowo, 2007; Gökçe, 2008; Li, 2009; Şenkal ve Dinçer, 2012; Yenal, 2009) şeklinde sıralanmaktadır. Bu çalışmada da okul yöneticileri tarafından teknik yetersizlik önemli bir sorun olarak görülmüştür. Bu sorun kapsamında okul yöneticileri öğretmenlerin sınırlı internetlerinin olması, bulundukları bölgelerde internetin olmaması, bazı öğretmen ve öğrencilerin tablet, bilgisayar gibi araç gereçlere sahip olmamalarının online eğitimleri ve yapılan etkinlikleri sekteye uğrattığını belirtmişlerdir. Öğrencisinden öğretmenine, okul yöneticisinden velisine kadar birçok kişinin uzaktan eğitime hazırlıksız olarak yakalanmış olması teknik sorunların oluşumuna sebebiyet verdiği düşünülmektedir.

Okul yöneticilerinin görüşleri doğrultusunda Covid-19 sürecinde öğretmen ilgisizliğinden kaynaklı sorunlar yaşamaları ele alınması gereken önemli bir konu olarak görülmektedir. Şüphesiz ki öğretmenler eğitim öğretim kurumlarının en önemli unsurlarıdır. Öğretmen, eğitimin temel taşıdır, onun niteliği doğrudan eğitimin niteliğini etkileyen etkenlerin başında gelmektedir (Aydın, Şahin ve Topal, 2008). Öğretmenler tarafından sağlanan eğitimin niteliği de bağlı oldukları okulun etkili olmasını sağlayan önemli bir faktördür (Seferoğlu, 2004). Öğretmenlerin işlerine verdikleri önem (Turhan, Demirli ve Nazik, 2012), işlerini yaparken doyum elde etmeleri, işlerine bağlı olmaları eğitim kurumlarının başarılı olmasını da sağlayacaktır. Öğretmenin bu davranışlar da bulunmayıp mesleğine aykırı davranışlarda bulunması, kendisini mesleğine ait hissetmemesi, mesleğin gerektirdiği işleri yapmaması da eğitimin amaçlarına ulaşmanın önünde engel olacaktır. Özellikle içinde bulunduğumuz süreçte öğrenci ile eğitim arasında bir köprü görevi gören öğretmenlerin işlerine dört elle sarılıp daha özveri ile çalışmaları eğitsel anlamda yaşanılacak kayıpları daha aza indireceği düşünülmektedir. Bu noktada öğretmenlere sunulacak destek önem arz etmektedir. Çalışmada elde edilen sonuç doğrultusunda okul yöneticileri bu destekleri sunmak adına bazı etkinlikler yaptıklarını belirtmişlerdir. Özellikle öğretmenlere süreçle ilgili aydınlatıcı bilgiler vererek, okula aidiyet duygusunu artırmaya yönelik söylemlerde bulunarak, maddi-manevi desteklerde bulunarak, bugünlerin geçici olduğunu daha güzel günlerin karşılanacağına dair teminat vererek, öğretmenlerle sürekli online iletişim halinde olarak onların sorunlarını, sıkıntılarını dinleyerek, öğretmenlere sürprizler yaparak, bu süreci kolaylaştıracak etkinlik ve seminerler düzenleyerek öğretmenlerinin motivasyonunu artırmaya çalıştıkları sonucu elde edilmektedir. $\mathrm{Bu}$ yapılan etkinliklerin öğretmenlerin motivasyonun artırmada ve kendilerini bu süreç içerisinde yalnız hissetmelerini önlemede önemli olduğu düşünülmektedir.

Bir okul yöneticisi okulunu ilgilendiren her konuya dahil olmak zorundadır. Bir okul, öğretmen, öğrenci, öğrenci velisi, yardımcı personeli içine alan kompleks bir yapıya sahip olduğundan okul yöneticisinin ise bu grupların hepsine hitap etmesi gerekmektedir. Yani bu süreç içerisinde okul yöneticilerinin sadece öğretmenleri değil, öğrencisi, velisi ve yardımcı personelleri üzerinde de desteğini hissettirmesi gerekmektedir. Araştırmada okul yöneticilerinin veli ve öğrencilerinin motivasyonunu sağlamada da rollerinin olduğunu bu rolleri bazen doğrudan kendileri aracılığıyla bazen de öğretmenleri vasıtasıyla gerçekleştirdikleri sonucuna ulaşılmıştır. Örneğin, velileri Covid-19 süreci ile bilgilendirmeleri, öğrencilerine gerek eğitim gerekse moral açıdan destek çalışmaları gerçekleştirmeleri okul yöneticilerinin kriz anında okulun her kesimine ulaşmaya çalıştıklarının bir göstergesidir.

Sonuç itibari ile dünya genelinde yaşanılan Covid-19 salgınının diğer sistemleri etkisi altına aldığı gibi eğitim sistemini de olumsuz olarak etkilediği açıkça ortadadır. Bu olumsuz etkinin en aza indirilmesinde liderlik görevini üstlenen okul yöneticilerine önemli görevler düşmektedir. Özellikle öğretmen, öğrenci ve velilerin motivasyonunun sağlanması ve bu süreçte eğitim öğretim 
faaliyetlerinin minimum seviyede sekteye uğrayarak devamını sağlanmasında da okul yöneticilerinin önemli bir etkisi olacaktır.

\section{Kaynakça}

Akbaba, A. (2020). Okul müdürlerinin liderlik özelliklerinin müdür yardımcılarının görüşlerine göre değerlendirilmesi. Academia Eğitim Araştırmaları Dergisi, 5(1), 141-155.

Aslan, R. (2020). Tarihten günümüze epidemiler, pandemiler ve Covid-19. Ayrıntı Dergisi, 8(85), $35-41$.

Aras, N. (2013). Okul müdürlerinin sahip olduğu okul liderliği standartlarına ilişskin ögretmen algıları. Yayımlanmamış yüksek lisans tezi, Eskişehir Osmangazi Üniversitesi, Eğitim Bilimleri Enstitüsü.

Argon, T. ve Zafer, D. (2009). İlköğretim okulu yöneticilerinin iletişim sürecinde yaşadıkları problemler (Nitel bir araștırma). Sakarya Üniversitesi Eğitim Fakültesi Dergisi, 18, 99-123.

Atak, M. ve Atik, İ. (2007). Örgütlerde sürekli eğitimin önemi ve öğrenen örgüt oluşturma sürecine etkisi. Journal of Aeronautics and Space Technologies, 3(1), 63-70.

Aydın, C.H. (2005). Açık ve uzaktan öğrenmede kullanılan basılı materyallerdeki anlatım biçimine ilişkin öğrenen tercihleri. Anadolu Üniversitesi Sosyal Bilimler Dergisi, 5(1), 131-147.

Aydın, R., Şahin, H. ve Topal, T. (2008). Türkiye'de ilköğretime sınıf öğretmeni yetiştirmede nitelik arayışları. TSA, 12(2), 119-142.

Bayar, A. (2015). Bir örgüt olarak okulda meydana gelen çatışma nedenleri ve çözüm yollarına yönelik okul müdürlerinin görüşleri. Sakarya University Journal of Education, 5(3), 130141.

Begimbetova, K. (2015). Uzaktan eğitimde öğretim elemanı ve öğrencilerin memnuniyet düzeyi. Yayımlanmamış yüksek lisans tezi, Gazi Üniversitesi/Bilişim Enstitüsü.

Bilgiç, H.G. ve Tüzün, H. (2015). Yükseköğretim kurumları web tabanlı uzaktan eğitim programlarında yaşanan sorunlar. Açıkögretim Uygulamaları ve Araştırmaları Dergisi, $1(3), 26-50$.

Bonk, C. (2001). Online teaching in an online world. http://www.publicationshare.com/docs/faculty_survey_report.pdf Erişim tarihi: 23.04.2020

Chen, N. S. \& Wang Y. P. (2008). Testing principles of language learning in a cyber face -to -face environment. Educational Technology \& Society, 11(3), 97 -113.

Çelikten, M. (2006). Okul kültürünün şekillendirilmesinde müdürün rolleri. Eğitim ve Bilim Dergisi, 31(140), 56-61.

Demir, D. H. (2019). Okul müdürleri liderlik stillerinin örgüt iklimi ve öğretmenlerin kolektif yeterlilik algısı üzerindeki etkisi. Yayımlanmamış yüksek lisans tezi, Maltepe Üniversitesi, Sosyal Bilimler Enstitüsü.

Duran, N., Önal, A. ve Kurtuluş, C. (2006). E-öğrenme ve kurumsal eğitimde yeni yaklaşım öğrenim yönetim sistemleri, Bilgi Teknolojileri Kongresi IV, Akademik Bilişim, Bildiriler Kitabl, 97-101.

Erol, F. (1995). Okul müdürlerinin görevlerini başarmada karşılaştıkları engeller (Burdur İli Örneği), Eğitim Yönetimi, 1(1), 1-8.

Ersoy, F. (2016). Fenomenoloji. A. Saban ve A. Ersoy (Ed.). Eğitimde nitel araşstırma içinde (s. 51105). An1 Yayınc1lı. 
Falowo, R. O. (2007). Factors impeding implementation of web-based distance learning. $A A C E$ Journal, 15(3), 315-338.

Fullan, M. (2002). The Change Leader. Educational Leadership, 59(8), 16-21. Erişim adresi: http://michaelfullan.ca/wp-content/uploads/2016/06/13396052090.pdf

Gökçe, A.T. (2008). Küreselleşme sürecinde uzaktan eğitim. Ziya Gökalp Eğitim Fakültesi Dergisi, $11,1-12$.

Gökyer, N. ve Namlı, A. (2015). Yöneticilerin maarif müfettişlerince yapılan kurum denetimine $\begin{array}{lllll}\text { yönelik algiları. } & \text { Turkish }\end{array}$ http://dx.doi.org/10.7827/TurkishStudies.8516

Güngör, S., Altınkaynak, Ş.Ö. ve Aksoy, N. (2018). Okulöncesi eğitim kurumlarında iletişim engelleri. S. Dinçer (Ed.). Değişen Dünyada Ĕgitim içinde (s. 30-42). Pegem Akademi Yayıncilik.

Güngör, S. ve Taşdan, M. (2016). Okul müdürlerinin perspektifinden ilköğretim okullarında iletişim engelleri, Mersin Üniversitesi Eğitim Fakültesi Dergisi, 12(1), 391- 409.

Ham, A. (2020). Social and economic impact of the COVID-19 and policy options in Honduras.Erişim adresi: https://www.undp.org/content/dam/rblac/Policy\%20Papers\%20COVID\%20 19/UNDPRBLAC-CD19-PDS-Number4-EN-Honduras.pdf (30.04.2020).

Koçak, Y. (1991). Okul-aile iletişiminin engelleri. Hacettepe Üniversitesi Eğitim Fakültesi Dergisi, 6, 129-133.

Li, X. (2009). Review of distance education used in higher education in China. Asian Journal of Distance Education, 7(2), 22-27.

Lunenburg, F. \& Ornstein, A. (2013). Educational administration-Eğitim yönetim, Nobel Yayın Dă̆ıtım.

Nobile, J. D. (2015). The directive communication of Australian primary school Principals. International Journal of Leadership in Education, 18 (2), 239-258. https://doi.org/10.1080/13603124.2014.932437.

Odabaş, H. (2003). Internet tabanlı uzaktan eğitim ve bilgi ve belge yönetimi. Türk Kütüphaneciliği, 17(1), 22-36.

Okumuş, A. (2017). Kamu özel ve ortaöğretim kurum müdürlerinin yönetsel davranışlarının incelenmesi: İstanbul Bakırköy örneği. Yayımlanmamış yüksek lisans tezi, İstanbul Sabahattin Zaim Üniversitesi, Sosyal Bilimler Enstitüsü.

Özlü, Ö. (2011). Uzaktan eğitim metoduyla sürdürülebilirlik eğitimi uygulamaları üzerine bir araştırma. Yayımlanmamış yüksek lisans tezi, Maltepe Üniversitesi, Sosyal Bilimler Enstitüsü.

Patton, M. Q. (2014). Nitel araştırma ve değerlendirme yöntemleri (M. Bütün \& S. B. Demir, Çev. Ed.) Pegem Akademi.

Sağlık Bakanlığı (2020). Covid-19 (Sars-CoV-2 enfeksiyonu) rehberi. Erişim adresi: https://covid19bilgi.saglik.gov.tr/depo/rehberler/COVID-19_Rehberi.pdf (30.04.2020).

Seferoğlu, S. S. (2004). Öğretmen yeterlikleri ve mesleki gelişim. Bilim ve Aklın Aydınlı̆̆ında Eğitim, 58, 40-45.

Seven, M. A. (2012). Uzaktan ve örgün eğitime devam eden öğrencilerin ingilizce dersindeki başarı düzeylerinin karşılaştırılması. Ekev Akademi Dergisi, 6(50), 215-228. 
Şenkal, O. ve Dinçer, S. (2012). Geleneksel sınıfların uzaktan eğitim platformuna dönüştürülmesi: Bir model çalışması. Biliş̧im Teknolojileri Dergisi, 5(1), 13-17.

Şimşek, Y. ve Altınkurt, Y. (2009). Endüstri meslek liselerinde görev yapan öğretmenlerin okul müdürlerinin iletişim becerilerine ilişkin görüşleri. Akademik Baklş, 17, 1-16.

Taymaz, H. (2019). Ilköğretim ve ortaöğretim okul müdürleri için okul yönetimi. Pegem Akademi Yayınc1lik.

Turhan, M., Demirli, C. ve Nazik, G. (2012). Sınıf öğretmenlerinin mesleğe adanmışlıklarına etki eden faktörler: Elazığ örneği. İstanbul Ticaret Üniversitesi Sosyal Bilimler Dergisi, 11(21), 179-192.

Tuncer, M. ve Taşpınar, M. (2008). Sanal ortamda eğitim ve öğretimin geleceği ve olası sorunlar. Sosyal Bilimler Dergisi, 10(1), 125-144.

UNESCO, (2020). COVID-19 educational disruption and response. Erişim Adresi: https://en.unesco.org/covid19/educationresponse (30.04.2020).

UNDP, (2020). Covid-19 pandemic. Erişim adresi: https://www.undp.org/content/undp/en/home/coronavirus.html (30.04.2020).

World Health Organization, (2020). Coronavirus disease 2019 (COVID-19): Situation report, 72.

Viner, R. M., Russell, S. J., Croker, H., Packer, J., Ward, J., Stansfield, C., Mytton, O., Bonell, C. \& Booy, R. (2020). School closure and management practices during coronavirus outbreaks including COVID-19: a rapid systematic review. The Lancet Child \& Adolescent Health, 4, 397-404. https://doi.org/10.1016/ S2352-4642(20)30095-X UCL

Yenal, A. Ç. (2009). Uzaktan eğitim. Yayımlanmamış yüksek lisans tezi, Yeditepe Üniversitesi, Sosyal Bilimleri Enstitüsü.

Yıldırım, A. ve Şimşek, H. (2018). Sosyal bilimlerde nitel araştırma yöntemleri. Seçkin Yayıncılık. 